Article

\title{
Optimization of the Production Technology of Oxidized Cyclodextrin Bisulfite
}

\author{
Yana-Ya Kostyro *, Anastasiya Soldatenko and Alexey Levchuk
}

A.E. Favorsky Irkutsk Institute of Chemistry Siberian Branch of the Russian Academy of Sciences, 1 Favorsky str., 664033 Irkutsk, Russia

* Correspondence: yanakos@irioch.irk.ru; Tel.: +7-(3952)-428225

Received: 30 May 2019; Accepted: 2 July 2019; Published: 4 July 2019

Abstract: The A.E. Favorsky Irkutsk Institute of Chemistry, Siberian Branch of the Russian Academy of Sciences has developed an original active pharmaceutical ingredient based on an oxidized cyclodextrin oligosaccharide, which is a bisulfite derivative. Conducted pharmacological studies proved its antiviral activity in vitro and in vivo experiments against the influenza A (H1N1) virus. The aim of this work was to optimize the technology of obtaining the active pharmaceutical ingredient based on the bisulfite derivative of oxidized cyclodextrin to increase the efficiency and safety of the process. For this, a scaled method of oligosaccharide oxidation was tested on pilot plants in accordance with the requirements of green chemistry. As a result, the reaction time was reduced from three to five days (laboratory conditions) to $1.5 \mathrm{~h}$, and the safety and environmental friendliness of process was ensured. The use of cross-flow filtration and the method of freeze-drying eliminated $96 \%$ of ethyl alcohol, reduced the laboriousness and energy consumption of the technological operations for purification and isolation of the final product, and also increased the productivity of the whole process (output increased to $98 \%$ ). The results are confirmed by data obtained by physicochemical methods.

Keywords: oligosaccharides; oxidation of carbohydrates; sodium periodate; cyclodextrin; active pharmaceutical ingredient; production technology

\section{Introduction}

It is known that seasonal influenza is a severe challenge for humanity. Influenza viruses affect various organs thus causing harm to human health. According to the World Health Organization (WHO)'s estimations, the annual influenza epidemics result in three to five million cases of the hypertoxic form (severe) of disease and 290,000-650,000 deaths from respiratory diseases caused by seasonal influenza. Influenza virus is characterized by a high rate of emergence of new virus strains, as well as the appearance of strains resistant to existing drugs [1,2].

All current influenza viruses are resistant to antiviral agents of the adamantanes class ( $\alpha$-methyl-1-adamantyl-methylamine hydrochloride and 1-aminoadamantane). These drugs block the M2 protein of the influenza A virus, which plays the role of ion channel in the viral membrane, thereby, preventing fusion of the virus membranes and the lysosomal vacuole [3].

The known inhibitors of viral neuraminidase (an enzyme necessary for the normal budding of virus particles and the manifestation of the infectious properties of the influenza virus) include zanamivir, oseltamivir, peramivir, and laninamivir [4-6]. However, they are characterized by a lower clinical efficacy and high cost of synthesis, which makes these drugs less accessible for widespread use.

The most interesting and promising anti-influenza compounds are sulfated oligo- and polysaccharides, heparinoids [7-10] that can interact directly with the influenza virus and other enveloped viruses such as the herpes or human immunodeficiency viruses, preventing their adsorption and internalization into the cell thus effectively inhibiting replication of the virus. However, wide 
application of heparinoids in medicine is restricted by their anticoagulant activity, which causes significant side effects. Among the latter the most dangerous is thrombocytopenia followed by heparin-induced thrombosis, osteoporosis, skin necrosis, alopecia, hypoaldosteronism, aggregation of blood platelets, and, most often, bleeding.

In the A.E. Favorsky Irkutsk Institute of Chemistry, Siberian Branch of the Russian Academy of Sciences (SB RAS) a substance, KS-6469 (see Figure 1), has been directly synthesized to create a new representative of semi-synthetic heparinoids, deprived of anticoagulant activity, on the basis of oligosaccharide ( $\beta$-cyclodextrin). Pharmacological studies have proven its antiviral activity in experiments in vitro and in vivo regarding the influenza A (H1N1) virus, as well as the lack of anticoagulant activity [11].

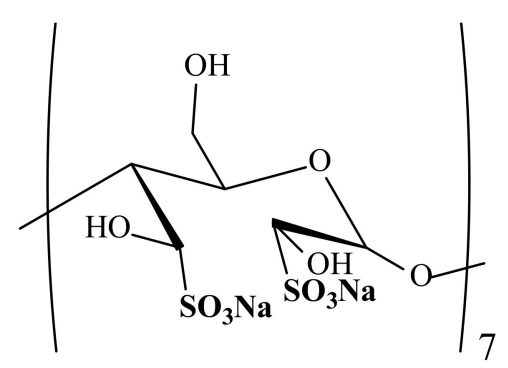

Figure 1. Chemical structure of the substance KS-6469 (fragment).

$\beta$-Cyclodextrin, a cyclic non-reducing homo-oligosaccharide, consists of seven $\alpha$-D-glucopyranose units linked by $(1 \rightarrow 4)$-glycosidic bonds. It has been chosen as an object of the study due to its widespread use in pharmaceutical practice.

The synthesis comprises a classic method for the preparation of oxidized carbohydrates (Malaprade periodate oxidation [12]) followed by nucleophilic addition of a sulfo-group [13]). The reaction affords a bisulfate derivative of the oxidized $\beta$-cyclodextrin bearing a bisulfite (or sulfonate) group coupled directly to the carbon atom $\mathrm{C}-\mathrm{SO}_{3}{ }^{-}$(C-sulfate).

$\mathrm{C}$-sulfates of various organic compounds (of non-carbohydrate nature) are known to exhibit a plethora of pharmacological activity (antiviral, anthelmintic, antiprotozoal, and antitumor) [14]. They are able to bind amyloids in experiments in vivo, and hence can be employed as potential agents for the treatment of Alzheimer's disease [15]. However, the application of this type of compounds is limited by high toxicity, nonselective receptor binding, and adverse side effects.

The following synthetic polymers also belong to C-sulfates:

- $\quad$ N-Sulfonate derivatives of poly(allylamine)hydrochloride with molecular mass of $56 \mathrm{kDa}$ and a degree of substitution of $98 \%$, which show strong antiviral activity against replications of influenza A virus in vitro and ex vivo mainly in the late infection stages [16];

- Polyanionic low molecular $(<10 \mathrm{kDa})$ sulfonate polymers, e.g., copolymers of urea and biphenyldisulfonic acid: Poly\{imino[2,2'-disulfo(1,1'-biphenyl)-4,4'-diyl]iminocarbonyl-1,4phenylen-carbonyl\} possessing antiviral activity against enveloped viruses, such herpes and human immunodeficiency viruses $[17,18]$.

Thus, the substance KS-6469, belonging to the class of C-sulfates, is a promising compound with antiviral activity.

Therefore, the purpose of this work is to optimize the technology for producing the substance KS-6469. It is necessary to scale up the synthesis in pilot plants in order to produce sufficient quantities of a substance to conduct a full cycle of its preclinical studies. 


\section{Materials and Methods}

\subsection{Reagents}

$\beta$-Cyclodextrin ( $\beta-C D)$ (KLEPTOSE ${ }^{\circledR}$, Roquette Freres, 62136 Lestrem, France), sodium (meta)periodate $\left(\mathrm{NaIO}_{4}\right)$ (Sigma-Aldrich ${ }^{\circledR}$, Saint Louis, $\left.\mathrm{MO}, \mathrm{USA}\right)$, and sodium pyrosulfite $\left(\mathrm{Na}_{2} \mathrm{~S}_{2} \mathrm{O}_{5}\right)$ (BASF, Ludwigshafen, Germany) were used in the work.

\subsection{Laboratory Procedure for the Synthesis of Substance KS-6469}

Oxidation of an aqueous solution $(18 \mathrm{mM})$ of $\beta-\mathrm{CD}(0.0009 \mathrm{~mol})$ was performed with an excess of $0.07 \mathrm{M}$ aqueous solution of $\mathrm{NaIO}_{4}(0.007 \mathrm{~mol})$ at $20{ }^{\circ} \mathrm{C}$ in the dark for five days $(\mathrm{pH} 4.5-5.0)$. Then $2 \mathrm{M}$ excess of $\mathrm{Na}_{2} \mathrm{~S}_{2} \mathrm{O}_{5}$ aquous solution $(0.05 \mathrm{~mol})$ was added to the reaction mixture. The target product was purified from low molecular impurities by dialysis against purified water for five to six days. The dialyzed solution was evaporated to a minimum volume (30-50 mL) and precipitated in $500 \mathrm{~mL}$ of $96 \%$ ethanol $\left(\mathrm{C}_{2} \mathrm{H}_{5} \mathrm{OH}\right)$. The solid product was dried in a vacuum, the yield was $60 \%$ with a moisture content of the final product of $10.71 \%$.

\subsection{Scaled-Up Procedure for the Synthesis of Substance KS-6469 in Pilot Plants}

The technology for the synthesis of substance KS-6469 was tested on pilot plants for the production of pharmaceutical substances.

Into a $5 \mathrm{~L}$ glass reactor with an outer cover made of light-tight fabric (Reactor-Ready ${ }^{\mathrm{TM}}$ with a jacket and standard binding (Radleys, UK)), purified water (1.25 L) was loaded via metering pump No. 1 and $\beta-C D(25 \mathrm{~g})$ was loaded via screw feeder No. 2. The dissolution was carried out with stirring using an overhead propeller stirrer with a rotational speed of $100 \mathrm{r} / \mathrm{min}$ at a temperature of $45^{\circ} \mathrm{C}$ maintained by an ultralow cooling Lauda Proline RP 845 thermostat $\left(-45 /+200{ }^{\circ} \mathrm{C}\right)$ (Lauda, Germany). The obtained $2 \%$ solution of $\beta-\mathrm{CD}$ was cooled to $20^{\circ} \mathrm{C}$. Next, $1.5 \%$ aqueous solution of $\mathrm{NaIO}_{4}(1.25 \mathrm{~L})$ was placed into the reactor via metering pump No. 1 and the mixture was oxidized upon continuous stirring (rotation rate of the stirrer was $50 \mathrm{r} / \mathrm{min}$ ) according to the established parameters ( 1 version: $\mathrm{T}=45^{\circ} \mathrm{C}, \mathrm{t}=18 \mathrm{~h} ; 2$ version: $\mathrm{T}=80^{\circ} \mathrm{C}, \mathrm{t}=1.5 \mathrm{~h}$ ). After the reaction completion, $38 \%$ aqueous solution of $\mathrm{Na}_{2} \mathrm{~S}_{2} \mathrm{O}_{5}(1.25 \mathrm{~L})$ was placed into the reactor via metering pump No. 3. The reaction mixture was cooled to $20^{\circ} \mathrm{C}$. The process completion was monitored by changing the color of the reaction mixture (from brown to light-yellow). The solution obtained was purified from mechanical impurities using a glass Nutsche filter NF10-L (3V Tech Group, Bergamo, Italy) connected to remote-controlled vacuum systems SC 920 (KNF Neuberger GmbH, Breisgau, Germany). The filtrate (V=3.5-3.7 L) was purified from lower molecular substances by the cross-flow filtration procedure. For this purpose, four to five flat-plate (cassette) filter elements made of polyethersulfone (PES) with a filtration area of $0.1 \mathrm{~m}^{2}$ and a nominal molecular weight of 1-5 kDa were placed into a tangential filtration system Sartocon ${ }^{\circledR}$ Slice (Sartorius Stedim Biotech, Göettingen, Germany). The filtration was carried out at filtrate flux rate of 3.0-3.5 L/m²/ $/ \mathrm{h}$ and transmembrane pressure (TMP) of 1.1-1.2 bar. The purification was performed for 4-6 h while continuously diluting the concentrate with purified water $(\mathrm{V}=5-7 \mathrm{~L})$ until the disappearance of periodate ion $\left(\mathrm{IO}_{4}{ }^{-}\right)$and bisulfite ions $\left(\mathrm{HSO}_{3}{ }^{-}\right)$in the permeate. The retentate formed $(\mathrm{V}=1-1.1 \mathrm{~L})$ was poured into $1 \mathrm{~L}$ glass round-bottom flasks, the latter being filled by $10 \%$. Deep retentate freezing was performed in a freezing device for round bottom flasks IKA ${ }^{\circledR}$ RW 20 digital (IKA ${ }^{\circledR}$, Königswinter, Germany) in the cooling bath CHRIST $^{\circledR}$ CB 18-40 (CHRIST ${ }^{\circledR}$, Osterode am Harz, Germany) with a rotation speed of $215-220 \mathrm{r} / \mathrm{min}$ and a bath temperature of $-33^{\circ} \mathrm{C}$. The target product was obtained by sublimation using a laboratory lyophilizer Beta 2-8 LDplus modified for organic solvents with a condenser temperature of $-85^{\circ} \mathrm{C}$ (CHRIST ${ }^{\circledR}$, Osterode am Harz, Germany). To reach the maximum rate of drying, the temperature was increased from +5 to $+20{ }^{\circ} \mathrm{C}$ at a rate of $2.5^{\circ} \mathrm{C} / \mathrm{h}$. After reaching the maximum temperature of the material $\left(+20^{\circ} \mathrm{C}\right)$, the final drying mode (temperature of the condenser $<-85^{\circ} \mathrm{C}$; pressure $<0.12 \mathrm{mbar}$ ) was applied during which vapor was removed from the dry product for $1.5 \mathrm{~h}$. 
Substance KS-6469 (1 version) was obtained at 98\% yield with a moisture content of $7.85 \%$.

Substance KS-6469 (2 version) was obtained at 96\% yield with a moisture content of $7.69 \%$.

\subsection{Methods of Instrumental Analysis}

The main experimental data were obtained using the material and technical base of the Baikal analytical center for collective use of the Siberian Branch of the Russian Academy of Sciences:

UV-spectra were recorded on a UV/VIS, Lambda 35 spectrometer (Perkin Elmer, Waltham, MA, USA) at 200-700 $\mathrm{nm}$.

The IR-spectra were recorded on a Vertex 70 infrared Fourier spectrometer (Bruker, Billerica, MA, USA) at $400-4000 \mathrm{~cm}^{-1}$ in $\mathrm{KBr}$ tablets.

The weight-average molecular weight $(\mathrm{Mw})$ was determined by high-performance exclusion chromatography on an Agilent Technologies 1260 Infinity chromatograph, PL aquagel-OH $408 \mathrm{~nm}$ column, $300 \times 7.5 \mathrm{~mm}$, refractometer detector, sample concentration $1 \mathrm{mg} / \mathrm{mL}$, sample volume $20 \mu \mathrm{L}$. Elution was performed with a $0.1 \mathrm{M}$ aqueous solution of lithium nitrate $\left(\mathrm{LiNO}_{3}\right)$ at $30{ }^{\circ} \mathrm{C}$ with an eluent rate of $1 \mathrm{~mL} / \mathrm{min}$. The column was calibrated using D-galactose and dextrans with molecular masses of 5, 12, and $25 \mathrm{kDa}$ (Sigma, Saint Louis, MO, USA). The calculations were performed using Agilent Chem Station software.

Elemental analysis (C, H, N, S, O) was performed on an automatic elemental analyzer, Flash 2000 (Thermo Scientific, Roma, Italy).

Moisture content was determined on a moisture analyzer MA-5 (Sartorius Stedim Biotech, Goettingen, Germany).

\section{Results and Discussion}

A laboratory method for the preparation of substance KS-6469 was carried out according to the following scheme (see Figure 2).

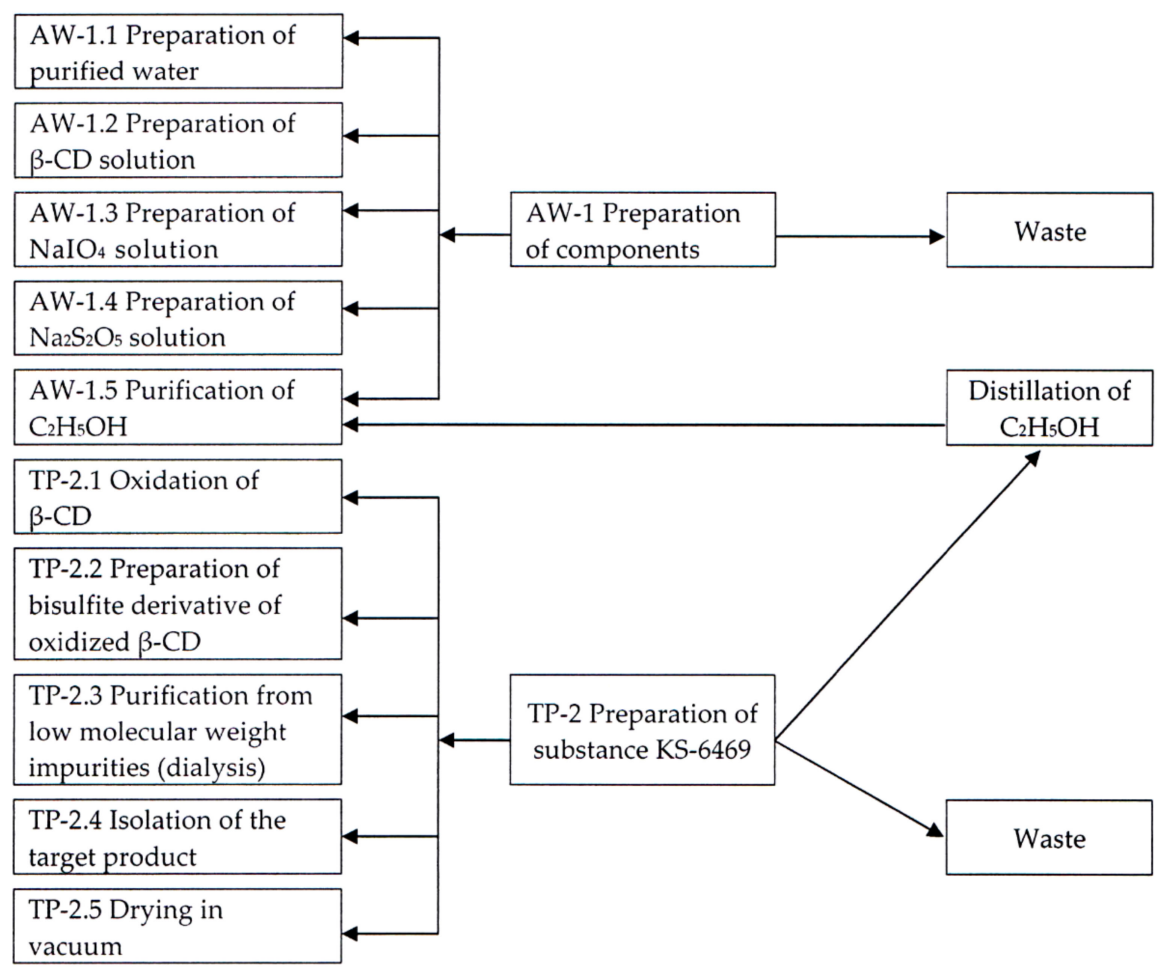

Note: AW- auxiliary work, TP - technological process

Figure 2. Technological scheme of obtaining the substance KS-6469 (laboratory procedure). 
The following stages are critical and require optimization to scale up the synthesis of substance KS-6469:

(Auxiliary work) AW-1.5: Purification of $\mathrm{C}_{2} \mathrm{H}_{5} \mathrm{OH}$

(Technological process) TP-2.1: Oxidation of $\beta-\mathrm{CD}$

TP-2.3: Purification of low molecular weight impurities (dialysis)

TP-2.4: Isolation of the target product

TP-2.5: Drying in vacuum.

Such technological stages of the laboratory synthesis of substance KS-6469 as AW-1.5, TP-2.3, and TP-2.4 are closely interrelated and highly energy consuming and inefficient. In addition, a significant technological disadvantage of this method is the use of a large amount of $\mathrm{C}_{2} \mathrm{H}_{5} \mathrm{OH}(96 \%)$ to isolate the target product (up to $500 \mathrm{~L}$ per $1 \mathrm{~kg}$ of $\beta-\mathrm{CD}$ ). The continuous regeneration of this organic solvent requires additional labor and production expenses.

Therefore, an industrial method for the production of substance KS-6469, including isolation and freeze-drying was developed. Its application allows completely excluding $\mathrm{C}_{2} \mathrm{H}_{5} \mathrm{OH}(96 \%)$ from the technology, as well as stage AW-1.5 and TP-2.5, which increases the efficiency and productivity of the process as a whole.

\subsection{Optimization of Stage TP-2.4 the Isolation of the Target Product}

Sublimation is not only a mild method of industrial drying of products, but one of the efficient routes to increase stability of unstable and thermolabile molecules. The employment of freeze-drying in the manufacture of pharmaceuticals is one of the ways to obtain high-quality drugs, since under the drying conditions the compounds undergo minimal chemical transformations that permits increased stability and yield of the target products [19,20].

A feasible method of freeze-drying consists of three main stages: Freezing, sublimation of ice (primary drying), and removal of residual moisture at temperatures above $0{ }^{\circ} \mathrm{C}$ (final drying).

\subsubsection{Freezing}

After completion of this stage, the substance acquires structure, which will define the conditions of sublimation and quality of the final product. Therefore, to prepare a solution of substance KS-6469 for sublimation, a method for rapid deep freeze is applied. The method allows the freezing of large volumes of solutions. The lyophilizer CHRIST ${ }^{\circledR}$ Beta 2-8 LDplus permits simultaneous drying of up to $5 \mathrm{~L}$ of solution on a 24-valve manifold. Optimal loading of the lyophilizer was determined to be a $1 \mathrm{~L}$ flask filled to $10 \%$, which yielded a drying rate of $1.2 \mathrm{~L}$ of solution for $6 \mathrm{~h}$.

Deep freezing was performed in a freezing device for round bottom flasks (IKA ${ }^{\circledR}$ RW 20 digital) in the cooling bath CHRIST ${ }^{\circledR}$ CB 18-40 with a rotation speed of $215-220 \mathrm{r} / \mathrm{min}$ and a bath temperature of $-33^{\circ} \mathrm{C}$ (see Figure S1).

Due to the centrifugal force, the liquid rises along the wall of the flask and is pre-frozen. The pre-freezing reduces the thickness of the solution layer (no more than $1 \mathrm{~cm}$ ), which ultimately has a positive effect on the duration of the drying process, significantly decreasing the total time.

These conditions for the preparation of substance KS-6469 solution promote its fairly rapid freezing. The freezing rate $(25 \mathrm{~mL} / \mathrm{min})$, which is defined as the rate of movement of the crystallization front from the surface into the substance depth, influences the shape and size of the crystals formed, and is a rather important characteristic of the process. Quick deep freezing leads to the formation of a large number of very small crystals, preventing the destruction of the substance structure and ensuring good solubility of the dried preparation [21,22].

\subsubsection{Primary Drying (Ice Sublimation)}

Freeze-drying is a complex diffusion process, which is determined by the rate of moisture diffusion from the depth of the frozen material (solid state) into the environment (in the form of vapor), that 
is, the frozen product is dried in vacuum without defrosting. However, the ice sublimation from the frozen product can only occur if the partial pressure of the vapor in the chamber of the lyophilizer is lower than pressure of water vapor over the product [23,24].

In the lyophilizer CHRIST ${ }^{\circledR}$ Beta 2-8 LDplus (see Supplementary Materials Figure S2a), an ice condenser with a temperature of up to $-85^{\circ} \mathrm{C}$ and a capacity of $6 \mathrm{~kg} / 24 \mathrm{~h}$ is an evaporation pump, since the moisture, which is evaporated under vacuum during the drying, "sticks" to its surface. The lyophilizer vacuum pump helps to reduce the partial pressure of non-condensable gases so that water vapor can transfer to the ice condenser.

However, to begin the sublimation, it is necessary to transfer energy to the product. This occurs during the drying in round flasks on the manifold by the surface absorption of thermal radiation evaporation due to a higher ambient temperature (direct contact). As soon as the sublimation of water vapor from the frozen product starts, heat is released and, therefore, the product continues to cool (a crust of ice is formed on the surface of the flask) (see Figure S2b). The maximum rate of sublimation is observed at the beginning of the drying process (up to $3 \mathrm{~h}$ ), when temperature of the condenser $\left(\mathrm{T}_{0}=-88^{\circ} \mathrm{C} \rightarrow \mathrm{T}_{1.0}=-78^{\circ} \mathrm{C} \rightarrow \mathrm{T}_{2.0}=-77^{\circ} \mathrm{C} \rightarrow \mathrm{T}_{3.0}=-87^{\circ} \mathrm{C}\right)$, and therefore pressure in the condenser chamber rises.

During this stage of the drying, it is important to precisely control the heat supply so that the temperature and pressure in the condenser chamber are maintained at the optimum level. Therefore, lyophilization of substance KS-6469 solution is performed to ensure the maximum drying rate at the initial ambient temperature of $+5^{\circ} \mathrm{C}$, increasing it with a rate of $2.5{ }^{\circ} \mathrm{C} / \mathrm{h}$ to $+20^{\circ} \mathrm{C}$. These parameters of the drying temperatures are required to maintain the pressure in the condenser chamber at the lowest level [25].

The primary drying stage results in completion of the sublimation of all ice fragments, when the temperature of the product becomes almost equal to the ambient temperature $\left(+20^{\circ} \mathrm{C}\right)$. In this case, the ice condenser is no longer loaded and reaches a constant final temperature of $-94^{\circ} \mathrm{C}$ and vacuum in the chamber rises to $0.47-0.48$ mbar ("cryo effect" of the condenser). It was experimentally established that these parameters should be maintained for at least $1 \mathrm{~h}$.

Thus, the material obtained after freeze-drying has a porous structure. The pores are formed in places where ice crystals have been previously located [26] (see Figure S3).

\subsubsection{Final Drying (Removal of Residual Moisture)}

The secondary sublimation (desorption) involves the removal of absorbed water (10-35\% of the initial water content in the substance) by changing the thermobaric conditions in the chamber [27]. For this, after reaching the maximum temperature of the material $\left(+20^{\circ} \mathrm{C}\right)$, the final drying mode (temperature of the condenser $<-85^{\circ} \mathrm{C}$; pressure $<0.12 \mathrm{mbar}$ ) was applied during which vapor was removed from the dry product for $1.5 \mathrm{~h}$. Completion of the process was determined by constant residual vapor pressure in the freezing chamber upon closing the vacuum line (pressure $=0.0032 \mathrm{mbar}$ ).

Thus, the freeze-drying at stage TP-2.4 allows substance KS-6469 to be obtained with a moisture content that is $30 \%$ lower than when $\mathrm{C}_{2} \mathrm{H}_{5} \mathrm{OH}$ was used as a precipitator at stage TP-2.4. The total time of freezing and drying of the substance was 8-9 h, which reduced the duration of stage TP-2.4 followed by the drying (stage TP-2.5) by two to four times.

\subsection{Optimization of Stage TP-2.3 Purification from Low Molecular Weight Impurities (Dialysis)}

In the laboratory protocols, dialysis, a laborious and inefficient technological operation (five to six days), is used to purify the products from low molecular weight impurities. As a result, the process for the preparation of substance KS-6469 becomes long, the yield of the final product decreases, and its appearance and elemental composition change due to possible destruction and degradation of the macromolecule. At the same time, dialysis is characterized by a high consumption of power and purified water, since multiple replacement of the dialysis environment is required to complete sample purification from impurities. 
This technological stage was optimized by using ultrafiltration as the method for purification of the target product from low molecular weight impurities. Ultrafiltration represents a process of membrane separation (fractionation, concentration, etc.) of substances owing to filtration of a liquid under the action of difference in pressure before and after membranes [28,29].

The most effective option for ultrafiltration is a cross-flow filtration, where the liquid flows to the membrane tangentially (along the membrane). In this way, a pressure difference across the entire membrane is created. Consequently, a certain volume of the fluid passes through the membrane in the form of a filtrate, and the remaining volume continues to move along the membrane together with impurities, which are purified in flux by the membrane walls [30,31].

The tangential filtration system Sartocon ${ }^{\circledR}$ Slice (Sartorius Stedim Biotech, Goettingen, Germany) includes flat-plate (cassette) filter elements made of polyethersulfone (PES) with a filtration area of $0.1 \mathrm{~m}^{2}$ and a nominal molecular weight of $1-5 \mathrm{kDa}$. These elements represent rectangular blocks containing a package of pairs of parallelly arranged membranes between which the drainage mesh layer is placed. Drainage layers are located at a distance of $0.5-5 \mathrm{~mm}$, forming an intermembrane space for a flux of the separated solution. The latter passes successively through the filter elements, is concentrated, and is removed, while the filtrate that has passed through the membrane leaves through the drainage layers in the radial direction (see Figure S4).

The presence of up to five PES filter elements in the Sartocon ${ }^{\circledR}$ Slice filter holder enables a significant reduction in the purification time of substance KS-6469 from five to six days (dialysis) to $4-6 \mathrm{~h}$. This parameter was achieved at a filtrate flux rate of $3.0-3.5 \mathrm{~L} / \mathrm{m}^{2} / \mathrm{h}$ and transmembrane pressure (TMP) of 1.1-1.2 bar (see Figure S5).

\subsection{Optimization of Stage TP-2.1 Oxidation of $\beta-C D$}

The main technological problem of the laboratory method for the preparation of substance KS-6469 is a very long (five days) duration of its synthesis, which is economically unprofitable when scaling up the process. Therefore, the research was focused on reduction of the reaction time by the optimization of experimental conditions.

To reach this goal, the moment of the reaction completion was established by spectrophotometric determination of $\mathrm{NaIO}_{4}$ consumption [32] (see Figure 3).

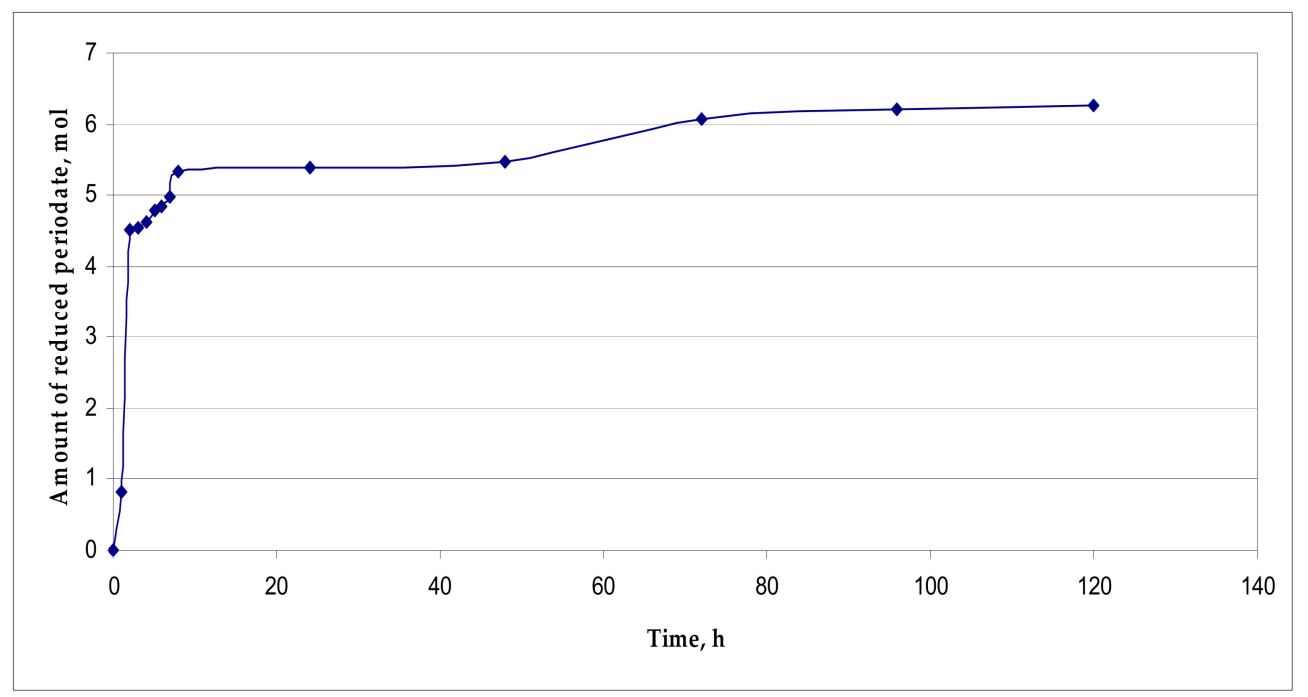

Figure 3. Consumption of $\mathrm{NaIO}_{4}$.

The curve of the consumption of $\mathrm{NaIO}_{4}$ shows that during the first $7 \mathrm{~h}$ of the reaction at $20^{\circ} \mathrm{C}$, a major amount of $\mathrm{NaIO}_{4}$ is consumed $\left(4.97 \pm 0.25 \mathrm{~mol} \mathrm{NaIO}_{4} / \mathrm{mol} \beta-\mathrm{CD}\right)$, and then the oxidation 
of the oligosaccharide slows down and by the fifth day it is almost completed $(6.23 \pm 0.31 \mathrm{~mol}$ $\left.\mathrm{NaIO}_{4} / \mathrm{mol} \beta-\mathrm{CD}\right)$.

Malaprade periodate oxidation of carbohydrates is a selective oxidation of the $\alpha$-glycol group, leading to the cleavage of the $\mathrm{C}-\mathrm{C}$ bond. In this process, 1 mol of $\mathrm{NaIO}_{4}$ is consumed for the oxidation of each $\alpha$-glycol group. Thus, the theoretical consumption of $\mathrm{NaIO}_{4}$ is $7 \mathrm{~mol}$ per $1 \mathrm{~mol}$ of $\beta$-CD.

When the reaction is carried out at $20^{\circ} \mathrm{C}$, the increased reconsumption of $\mathrm{NaIO}_{4}$ is not observed (its consumption is $89 \%$ of the theoretically possible), although according to the protocol it is taken in a small excess ( $8 \mathrm{~mol}$ of $\mathrm{NaIO}_{4} / \mathrm{mol} \beta-\mathrm{CD}$ ). This indicates the absence of non-specific oxidation processes, as well as "over-oxidation" processes, which result in the formation of malondialdehyde (MDA) or malonic acid derivatives, which can also be oxidized.

To confirm the absence of MDA derivatives in the reaction mixture, spectrophotometric studies were performed in the region of 200-300 nm (MDA in its native form has a fairly good absorption at $\lambda_{\max }=245 \mathrm{~nm}$ and $\lambda_{\max }=267 \mathrm{~nm}$ ) [33] (see Figure 4).

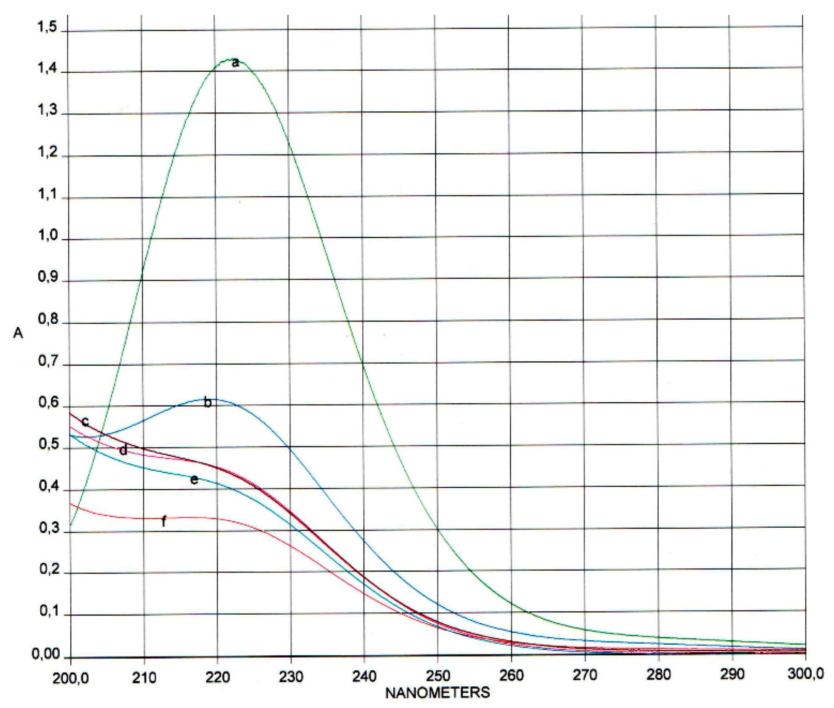

Figure 4. Absorption spectrum of the reaction mixture at $20{ }^{\circ} \mathrm{C}$ at various times (t, h): (a) 0 ; (b) 3 ; (c) 6 ; (d) $24 ;$ (e) 72 ; (f) 120 .

The spectra show that the reaction mixture has a single absorption maximum at $\lambda_{\max }=223 \mathrm{~nm}$, which corresponds to the specific absorption of periodate ion $\left(\mathrm{IO}_{4}^{-}\right)$[34]. Even on the fifth day of the reaction, the formation of MDA was not detected.

Thus, stage TP-2.1 of the preparation of substance KS-6469, which takes five days at $20^{\circ} \mathrm{C}$, was not accompanied by side reactions. The main oxidation of $\beta$-CD occurs in the first $5-7 \mathrm{~h}$ of the reaction, with the consumption of $\mathrm{NaIO}_{4}$ being $71 \%$ of the theoretically possible.

The rate of the chemical reaction is known to depend on temperature and is determined by the van ' $t$ Hoff equation. According to the latter, an increase in temperature of every $10^{\circ} \mathrm{C}$ increases the rate constant of a homogeneous elementary reaction by two to four.

Having recalculated the dependence of $\beta-\mathrm{CD}$ oxidation time on temperature, the following process parameters were selected for the study:

1. $\mathrm{T}=45^{\circ} \mathrm{C} ; \mathrm{t}=18 \mathrm{~h}$

2. $\mathrm{T}=80^{\circ} \mathrm{C} ; \mathrm{t}=1.5 \mathrm{~h}$.

Using these parameters, the kinetics of $\beta-C D$ oxidation was studied (see Figure 5), and the reactions of non-specific oxidation were monitored (see Figure 6). 


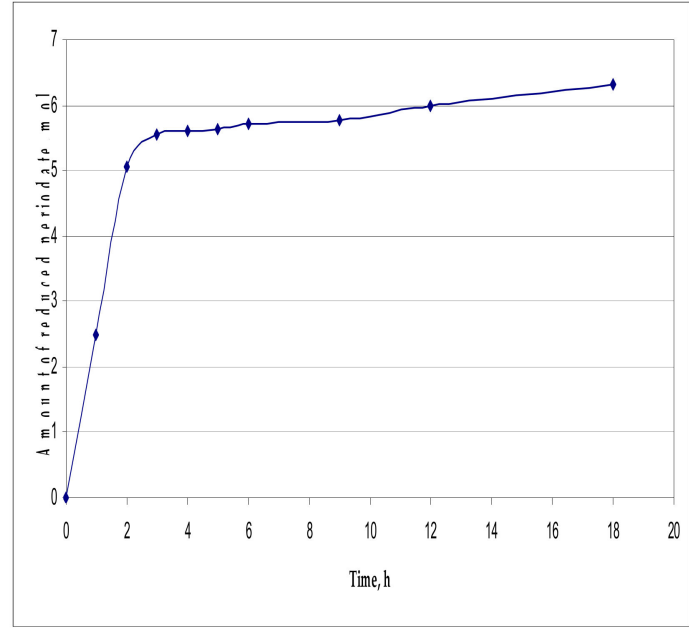

(a)

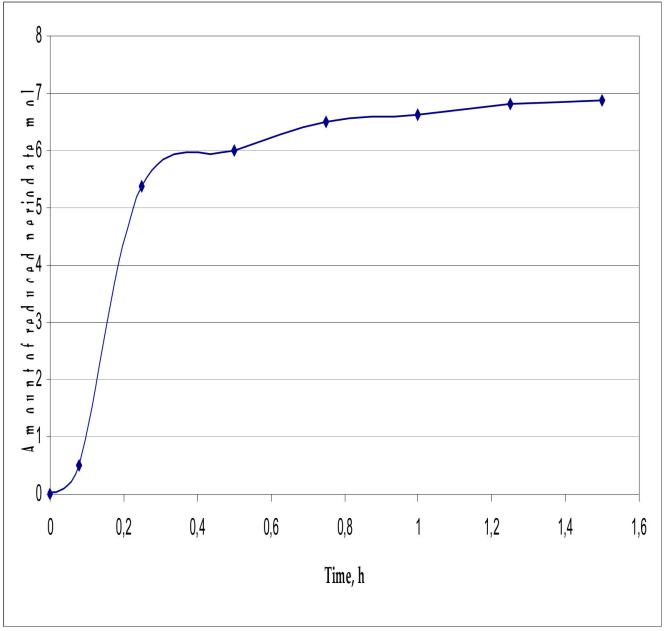

(b)

Figure 5. Consumption of $\mathrm{NaIO}_{4}:(\mathbf{a}) \mathrm{T}=45^{\circ} \mathrm{C} ; \mathrm{t}=18 \mathrm{~h} ;(\mathbf{b}) \mathrm{T}=80^{\circ} \mathrm{C} ; \mathrm{t}=1.5 \mathrm{~h}$.

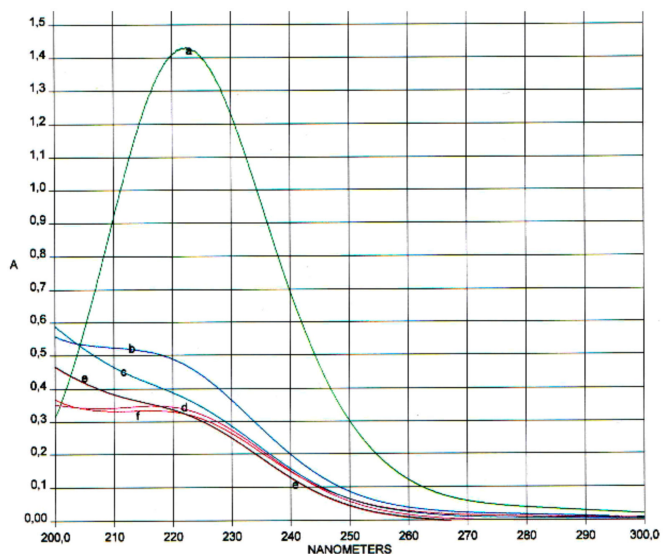

(a)

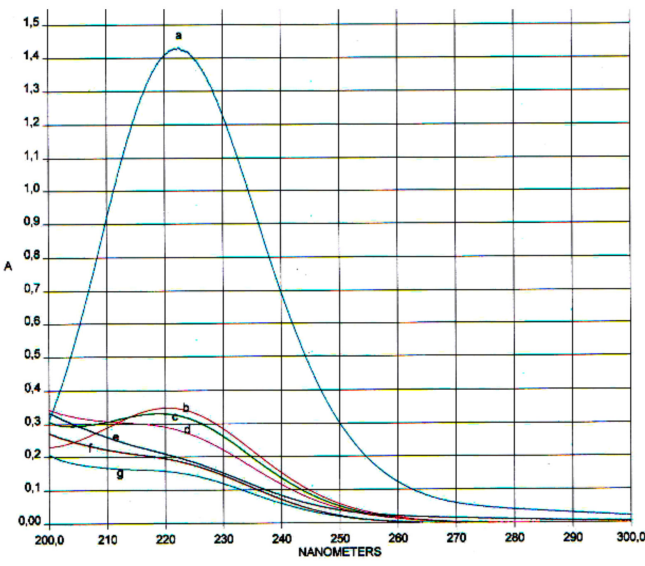

(b)

Figure 6. Absorption spectra of the reaction mixture: (a) $\mathrm{T}=45^{\circ} \mathrm{C}$ at various times (t, h): (a) 0; (b) 3; (c) 6 ; (d) 9 ; (e) 12 ; (f) 18 ; (b) $\mathrm{T}=80^{\circ} \mathrm{C}$ at various times (t, h): (a) 0 ; (b) 0.25 ; (c) 0.5 ; (d) 0.75 ; (e) 1.0 ; (f) 1.25 ; (g) 1.5 .

The results are shown in Table 1.

Table 1. Comparative characteristics of the $\beta-C D$ oxidation process using different parameters.

\begin{tabular}{|c|c|c|c|c|}
\hline Entry & $\begin{array}{c}\text { Process } \\
\text { Parameters }\end{array}$ & $\begin{array}{l}\text { Reaction } \\
\text { Time }\end{array}$ & $\begin{array}{l}\text { Consumption of } \mathrm{NaIO}_{4} \\
\text { (mol/mol } \beta-\mathrm{CD} / \% \text { to } \\
\text { Theoretically Possible) }\end{array}$ & $\begin{array}{l}\text { The Presence of the Absorption } \\
\text { of the Reaction Mixture to the } \\
\text { End of the Reaction at } \lambda_{\max }= \\
245 \mathrm{~nm} \text { and } \lambda_{\max }=267 \mathrm{~nm}\end{array}$ \\
\hline 1 & $\begin{array}{l}\mathrm{T}=20^{\circ} \mathrm{C} \\
\mathrm{t}=120 \mathrm{~h}\end{array}$ & 95-100 h & $6.23 \pm 0.31 \mathrm{~mol} / 89.0 \%$ & Not detected \\
\hline 2 & $\begin{array}{c}\mathrm{T}=45^{\circ} \mathrm{C} \\
\mathrm{t}=18 \mathrm{~h}\end{array}$ & $17-18 \mathrm{~h}$ & $6.16 \pm 0.29 \mathrm{~mol} / 87.9 \%$ & Not detected \\
\hline 3 & $\begin{aligned} \mathrm{T} & =80^{\circ} \mathrm{C} \\
\mathrm{t} & =1.5 \mathrm{~h}\end{aligned}$ & $1.25-1.5 \mathrm{~h}$ & $6.84 \pm 0.34 \mathrm{~mol} / 97.7 \%$ & Not detected \\
\hline
\end{tabular}

As can be seen from the presented data, the most complete oxidation of $\beta-C D$ without side reactions was achieved using an elevated temperature $\left(80^{\circ} \mathrm{C}\right)$ for $1.5 \mathrm{~h}$.

After conducting stage TP-2.2 of obtaining substance KS-6469, as well as the optimized stages TP-2.3 and TP-2.4, the corresponding target products $(\mathbf{1 a}-\mathbf{c})$ were synthesized. They represent white 
amorphous powders with high hygroscopicity. Their physical-chemical properties are presented in Table 2 and Figure 7.

Table 2. Physical-chemical characteristics of compounds 1a-c.

\begin{tabular}{|c|c|c|c|c|c|c|c|c|c|}
\hline \multirow{2}{*}{$\begin{array}{l}\text { Compound/ } \\
\text { Empirical } \\
\text { Formula }\end{array}$} & \multirow{2}{*}{$\begin{array}{c}\text { Process } \\
\text { Parameters }\end{array}$} & \multirow{2}{*}{$\begin{array}{c}\text { Yield } \\
(\%)\end{array}$} & \multirow{2}{*}{$\begin{array}{l}\text { Moisture } \\
\text { Content } \\
(\%)\end{array}$} & \multirow{2}{*}{$\begin{array}{l}\text { Mw (kDa) } \\
\text { Found } \\
\text { Calculated }\end{array}$} & \multirow{2}{*}{$\underset{\left(\mathrm{cm}^{-1}\right)}{\mathrm{IR}}$} & \multicolumn{4}{|c|}{ Calculated $(\%)$} \\
\hline & & & & & & $C$ & $\mathbf{H}$ & $S$ & $\mathrm{Na}$ \\
\hline $\begin{array}{c}\beta-\mathrm{CD} \\
\left(\mathrm{C}_{6} \mathrm{H}_{10} \mathrm{O}_{5}\right)_{7}\end{array}$ & - & - & 13.46 & 1.135 & - & $\frac{39.23}{44.41}$ & $\frac{6.65}{6.17}$ & - & - \\
\hline$\underset{\left(\mathrm{C}_{6} \mathrm{H}_{10} \mathrm{Na}_{2} \mathrm{O}_{11} \mathrm{~S}_{2}\right)_{7}}{\mathbf{1 a}}$ & $\begin{aligned} \mathrm{T} & =20^{\circ} \mathrm{C} \\
\mathrm{t} & =120 \mathrm{~h}\end{aligned}$ & 60 & 10.71 & $\frac{3.112}{2.576}$ & $\begin{array}{c}1311, \\
1144, \\
625 \\
\left(\mathrm{C}-\mathrm{SO}_{3}{ }^{-}\right)\end{array}$ & $\frac{20.74}{19.57}$ & $\frac{3.31}{2.72}$ & $\frac{14.85}{17.39}$ & $\frac{10.84}{12.50}$ \\
\hline$\frac{\mathbf{1 b}}{\left(\mathrm{C}_{6} \mathrm{H}_{10} \mathrm{Na}_{2} \mathrm{O}_{11} \mathrm{~S}_{2}\right)_{7}}$ & $\begin{array}{c}\mathrm{T}=45^{\circ} \mathrm{C} \\
\mathrm{t}=18 \mathrm{~h}\end{array}$ & 98 & 7.85 & $\frac{3.263}{2.576}$ & $\begin{array}{c}1314, \\
1143, \\
626 \\
\left(\mathrm{C}-\mathrm{SO}_{3}{ }^{-}\right) \\
\end{array}$ & $\frac{20.34}{19.57}$ & $\frac{2.39}{2.72}$ & $\frac{14.14}{17.39}$ & $\frac{11.98}{12.50}$ \\
\hline$\underset{\left(\mathrm{C}_{6} \mathrm{H}_{10} \mathrm{Na}_{2} \mathrm{O}_{11} \mathrm{~S}_{2}\right)_{7}}{\mathbf{1 c}}$ & $\begin{aligned} \mathrm{T} & =80^{\circ} \mathrm{C} \\
\mathrm{t} & =1.5 \mathrm{~h}\end{aligned}$ & 96 & 7.69 & $\frac{3.187}{2.576}$ & $\begin{array}{c}1321 \\
1149 \\
626 \\
\left(\mathrm{C}-\mathrm{SO}_{3}{ }^{-}\right)\end{array}$ & $\frac{20.11}{19.57}$ & $\frac{2.68}{2.72}$ & $\frac{13.67}{17.39}$ & $\frac{11.02}{12.50}$ \\
\hline
\end{tabular}

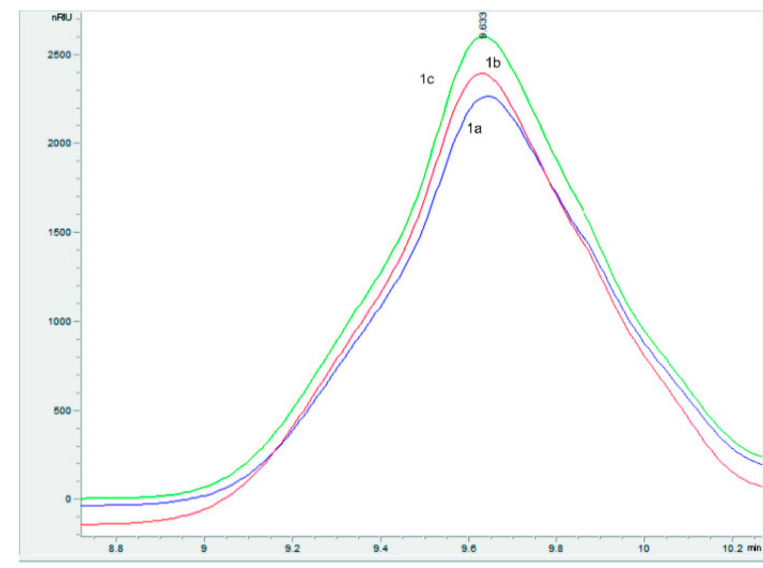

Figure 7. Chromatogram of high-performance exclusion chromatography of compounds 1a-c.

As follows from the above data, compounds 1a, 1b, and 1c, which are substance KS-6469 obtained under various conditions, are complete analogs.

Optimization of the technology for preparation of substance KS-6469 allowed finding the optimum parameters of not only synthesis $\left(\mathrm{T}=80^{\circ} \mathrm{C}, \mathrm{t}=1.5 \mathrm{~h}\right)$, but also purification of the target products from low molecular weight compounds (cross-flow filtration for 4-6 h using up to five PES filter elements with an area of $0.1 \mathrm{~m}^{2}$ and a nominal cut-off molecular weight of 1-5 kDa at filtrate flow rate $3.0-3.5 \mathrm{~L} / \mathrm{m}^{2} / \mathrm{h}$ and TMP $=1.1-1.2 \mathrm{bar}$ ). In addition, the use of the industrial sublimation method (lyophilization on the manifold upon direct contact with the medium in round-bottom flasks with pre-prepared deep freeze product (load $10 \%)$ in the modes of main $\left(\mathrm{T}_{\text {condenser }}[-77 ;-94]^{\circ} \mathrm{C}\right.$; condenser vacuum [1.0; 0.47-0.48] mbar; $\mathrm{t}=6-7 \mathrm{~h})$ and final drying $\left(\mathrm{T}_{\text {condenser }}<-85^{\circ} \mathrm{C}\right.$; condenser vacuum $<$ $0.12 \mathrm{mbar} ; \mathrm{t}=1.5 \mathrm{~h}$ ) enabled to combine the stages of isolation and drying of the final product. As a result the total time of substance KS-6469 synthesis was reduced from 12 days to about 16-17 $\mathrm{h}$.

Also, the employment of modern technological equipment in the pilot plant for the production of pharmaceutical substances and optimization of the process for obtaining bisulfite derivatives of oxidized $\beta$-CD permitted increased yield of the target product to $96-98 \%$.

The final optimized scheme of pilot plant production of substance KS-6469 is shown in Figure 8. 


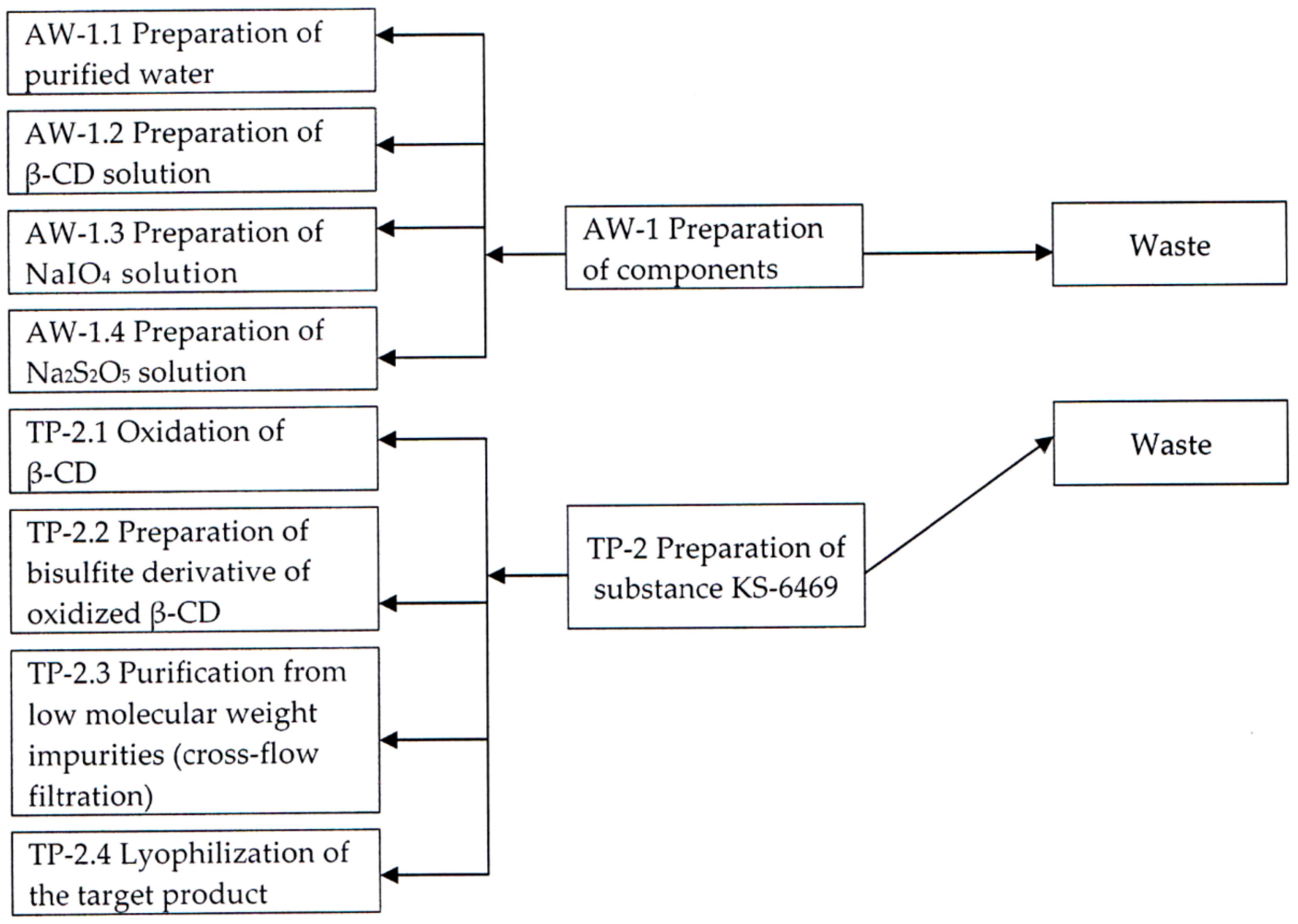

Note: AW- auxiliary work, TP - technological process

Figure 8. Optimized technological scheme of obtaining the substance KS-6469.

\section{Conclusions}

In conclusion, a technology for the synthesis of substance KS-6469 has been developed. The technology meets the requirements of "green chemistry" $\left(\mathrm{C}_{2} \mathrm{H}_{5} \mathrm{OH}\right.$ is excluded from the process), and is efficient and highly profitable compared to the laboratory method of production.

The high-tech method for the preparation of substance KS-6469 will allow sufficient amounts of the active pharmaceutical ingredient to be obtained in order to perform a full cycle of preclinical studies, which is the first step in the development of a new antiviral agent.

Supplementary Materials: The following are available online at http://www.mdpi.com/2227-9717/7/7/426/s1, Figure S1: Equipment for freezing substance KS-6469 (general view), Figure S2: Equipment for freeze-drying of substance KS-6469: (a) General view); (b) The beginning of sublimation (a crust of ice is formed on the surface of the flask), Figure S3: Appearance of a freeze-dried substance KS-6469, Figure S4: PES membrane with a filtration area of $0.1 \mathrm{~m}^{2}$ (general view), Figure S5: Equipment for tangential filtration of the substance solution KS-6469 (general view).

Author Contributions: Conceptualization, Y.-Y.K.; methodology, Y.-Y.K.; software, A.L.; validation, Y.-Y.K. and A.L.; formal analysis, A.S.; investigation, Y.-Y.K., A.S., and A.L.; resources, Y.-Y.K.; data curation, Y.-Y.K.; writing—original draft preparation, Y.-Y.K.; writing—review and editing, Y.-Y.K., A.S., and A.L.; visualization, A.L.; supervision, Y.-Y.K.; project administration, Y.-Y.K.

Funding: The work was performed according to the plans of research (state task) under the program V.48. Fundamental physical-chemical studies of the mechanisms of physiological processes and the creation on their basis of pharmacological substances and dosage forms for the treatment and prevention of socially significant diseases (2013-2020) (Project V.48.1.2. The search for new biologically active substances based on conifer biomass of Siberia and The Far East, screening of the biological activity of promising compounds. Development of technologies for the production of natural substances and the determination of their practical significance).

Acknowledgments: The authors are grateful to Anna Soldatenko and Alla Shulunova for their help in this work.

Conflicts of Interest: The authors declare no conflict of interest. 


\section{References}

1. Global Influenza Strategy 2019-2030. Available online: https://www.who.int/influenza/en/ (accessed on 17 April 2019).

2. Samson, M.; Pizzorno, A.; Abed, Y.; Boivin, G. Influenza virus resistance to neuraminidase inhibitors. Antiviral Res. 2013, 98, 174-185. [CrossRef] [PubMed]

3. Scholtissek, C.; Quack, G.; Klenk, H.D.; Webster, R.G. How to overcome resistance of influenza a viruses against adamantane derivatives. Antiviral Res. 1998, 37, 83-95. [CrossRef]

4. Woodhead, M.; Lavanchy, D.; Johnston, S.; Colman, P.; Fleming, D. Neuraminidase inhibitors: Progress in the management of influenza. Int. J. Clin. Pract. 2000, 54, 604-610.

5. O'Malley, P. Intravenous peramivir emergency use authorization 2009: Update for the clinical nurse specialist. Clin. Nurse Spec. 2010, 24, 51-53. [CrossRef] [PubMed]

6. Fiore, A.E.; Fry, A.; Shay, D.; Gubareva, L.; Bresee, J.S.; Uyeki, T.M. Antiviral agents for the treatment and chemoprophylaxis of influenza-recommendations of the Advisory Committee on Immunization Practices (ACIP). MMWR Recomm. Rep. 2011, 60, 1-24. [PubMed]

7. Fitton, J.H. Therapies from fucoidan; Multifunctional marine polymers. Mar. Drugs 2011, 9, 1731-1760. [CrossRef] [PubMed]

8. Leibbrandt, A.; Meier, C.; König-Schuster, M.; Weinmüllner, R.; Kalthoff, D.; Pflugfelder, B.; Graf, P.; Frank-Gehrke, B.; Beer, M.; Fazekas, T.; et al. Iota-carrageenan is a potent inhibitor of influenza A virus infection. PLoS ONE 2010, 5, e14320. [CrossRef] [PubMed]

9. Grassauer, A.; Weinmuellner, R.; Meier, C.; Pretsch, A.; Prieschl-Grassauer, E.; Unger, H. Iota-Carrageenan is a potent inhibitor of rhinovirus infection. Virol. J. 2008, 5, 107. [CrossRef]

10. Tang, F.; Chen, F.; Li, F. Preparation and potential in vivo anti-influenza virus activity of low molecular-weight K-carrageenans and their derivatives. J. Appl. Polym. Sci. 2013, 127, 2110-2115. [CrossRef]

11. Kostyro, Y.A.; Goncharova, E.P.; Soldatenko, A.S.; Zenkova, M.A.; Vlasov, V.V.; Ivanov, A.V. Means with antiviral activity against influenza virus. Assignees: Institute of Chemical Biology and Fundamental Medicine, Siberian Branch of the Russian Academy of Sciences, The A.E. Favorsky Irkutsk Institute of Chemistry, Siberian Branch of the Russian Academy of Sciences. RU Patent 2,635,765, 15 November 2017.

12. Guthrie, R.D. Periodate Oxidation. Experimental conditions. In Methods in Carbohydrate Chemistry: Analysis and Preparation of Sugars; Whistler, R.L., Wolfrom, M.L., Eds.; Academic Press: New York, NY, USA, 1962; Volume 1, pp. 432-435.

13. Ingles, D.L. Chemistry of non-enzymic browning. V. The preparation of Aldose-Potassium bisulphite addition compounds and some amine derivatives. Aust. J. Chem. 1959, 12, 97-101.

14. Linhardt, R.J.; Toida, T. Heparin oligosaccharides: New analogues development and applications. In Carbohydrates in Drug Design; Witczak, Z.J., Nieforth, K.A., Eds.; Marcel Dekker: New York, NY, USA, 1997; pp. 277-341.

15. Kisilevsky, R.; Lemieux, L.J.; Fraser, P.E.; Kong, X.; Hultin, P.G.; Szarek, W.A. Arresting amyloidosis in vivo using small-molecule anionic sulphonates or sulphates: Implications for Alzheimer's disease. Nat. Med. 1995, 1, 143-148. [CrossRef] [PubMed]

16. Ciejka, J.; Milewska, A.; Wytrwal, M.; Wojarski, J.; Golda, A.; Ochman, M.; Nowakowska, M.; Szczubialka, K.; Pyrc, K. Novel polyanions inhibiting replication of influenza viruses. Antimicrob. Agents Chemother. 2016, 60, 1955-1966. [CrossRef] [PubMed]

17. Cardin, A.D.; Jackson, R.L.; Mullins, M.J. Anti-herpes virus and cytomegalovirus polyamide oligomers. Assignees: Merrell Pharmaceuticals Inc. (Cincinnati, OH), The Dow Chemical Co. (Midland, MI). US Patent 5728731A, 17 March 1998.

18. Ahmed, S.P.; Cardin, A.D.; Bridges, C.G.; Jackson, R.L.; Mullins, M.J.; Tyms, A.S. Potent inhibition of herpes simplex virus by MDL 101028, a Novel biphenyl disulfonic acid urea co-polymer. Antiviral. Chem. Chemother. 1995, 6, 34-42. [CrossRef]

19. Sadikoglu, H.; Ozdemir, M.; Seker, M. Freeze-drying of pharmaceutical products: Research and development needs. Dry. Technol. 2006, 24, 849-861. [CrossRef]

20. Tang, X.C.; Pikal, M.J. Design of freeze-drying processes for pharmaceuticals: Practical advice. Pharm. Res. 2004, 21, 191-200. [CrossRef] [PubMed] 
21. Patapoff, T.W.; Overcashier, D.E. The importance of freezing on lyophilization cycle development. BioPharm 2002, 15, 16-21.

22. Kasper, J.C.; Friess, W. The freezing step in lyophilization: Physico-chemical fundamentals, freezing methods and consequences on process performance and quality attributes of biopharmaceuticals. Eur. J. Pharm. Biopharm. 2011, 78, 248-263. [CrossRef] [PubMed]

23. Chouvenc, P.; Vessot, S.; Andrieu, J.; Vacus, P. Optimization of the freeze-drying cycle: A new model for pressure rise analysis. Dry. Technol. 2004, 22, 1577-1601. [CrossRef]

24. Ganguly, A.; Nail, S.L.; Alexeenko, A.A. Rarefied gas dynamics aspects of pharmaceutical freeze-drying. Vacuum 2012, 86, 1739-1747. [CrossRef]

25. Tang, X.C.; Nail, S.L.; Pikal, M.J. Freeze-drying process design by manometric temperature measurement: Design of a smart freeze-dryer. Pharm. Res. 2005, 22, 685-700. [CrossRef]

26. Trelea, I.C.; Passot, S.; Fonseca, F.; Marin, M. An interactive tool for the optimization of freeze-drying cycles based on quality criteria. Dry. Technol. 2007, 25, 741-751. [CrossRef]

27. Wei, W.; Mo, C.; Guohua, C. Issues in freeze drying of aqueous solutions. Chin. J. Chem. Eng. 2012, 20, 551-559. [CrossRef]

28. Jönsson, A.-S.; Trägårdh, G. Fundamental principles of ultrafiltration. Chem. Eng. Process. 1990, $27,67-81$. [CrossRef]

29. Kuriyel, R.; Fushijima, M.; Jung, C.W. Advancements in membrane processes for pharmaceutical applications. In Handbook of Membrane Separations: Chemical, Pharmaceutical, Food and Biotechnological Applications, 2nd ed.; Pabby, A.K., Rizvi, S.S.H., Sastre, A.M., Eds.; CRC Press: Boca Raton, FL, USA, 2015; pp. 403-418.

30. Davis, R.H. Theory of cross-flow filtration. In Membrane Handbook; Winston Ho, W.S., Sirkar, K.K., Eds.; Van Nostrand Reinhold: New York, NY, USA, 1992; pp. 480-505.

31. Genovesi, C.S. Several uses for tangential-flow filtration in the pharmaceutical industry. PDA J. Pharm. Sci. Technol. 1983, 37, 81-86.

32. Dixon, J.S.; Lipkin, D. Spectrophotometric determination of vicinal glycols. Anal. Chem. 1954, 26, 1092-1093. [CrossRef]

33. Marnett, L.J.; Bienkowski, M.J.; Raban, M.; Tuttle, M.A. Studies of the hydrolysis of ${ }^{14}$ C-labeled tetraethoxypropane to malondialdehyde. Anal. Biochem. 1979, 99, 458-463. [CrossRef]

34. Crouthamel, C.E.; Meek, H.V.; Martin, D.S.; Banks, C.V. Spectrophotometric studies of dilute aqueous periodate solutions. J. Am. Chem. Soc. 1949, 71, 3031-3035. [CrossRef] 